\title{
Inhibitory Concentration Net Assessment Measurement
}

National Cancer Institute

\section{Source}

National Cancer Institute. Inhibitory Concentration Net Assessment Measurement. NCI Thesaurus. Code C116255.

An indication of reduced or increased susceptibility of a viral org anism, or activity of a biological/biochemical reaction in response to the inhibitory concentration (IC50 and/or IC95) of a specific drug. 